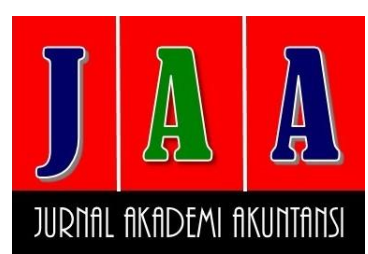

Website:

ejournal.umm.ac.id/index.php/jaa

Afiliasi:

1,2Fakultas Ekonomi, Universitas Teuku Umar, Meulaboh, Indonesia

* Correspondence:

budianto@utu.ac.id

DOI: $10.22219 /$ jaa.v4i2.18124

Sitasi:

Budianto, \& Sofyan, D.A. (2021). Analisis Perbandingan Kinerja

Keuangan Bank Aceh Sebelum Dan Sesudah Konversi Syariah. Jurnal Akademi Akuntansi, 4(2), 288-300.

Proses Artikel

Diajukan:

19 September 2021

Direviu:

22 September 2021

Direvisi:

28 Oktober 2021

Diterima:

29 Oktober 2021

Diterbitkan:

30 November 2021

\author{
Alamat Kantor: \\ Jurusan Akuntansi Universitas \\ Muhammadiyah Malang \\ Gedung Kuliah Bersama 2 \\ Lantai 3. \\ Jalan Raya Tlogomas 246, \\ Malang, Jawa Timur, \\ Indonesia
}

P-ISSN: 2715-1964

E-ISSN: 2654-8321
Tipe Artikel: Paper Penelitian

\section{ANALISIS PERBANDINGAN KINERJA KEUANGAN BANK ACEH SEBELUM DAN SESUDAH KONVERSI SYARIAH Budianto $^{1 *}$, Dara Angreka Sofyan ${ }^{2}$}

\section{ABSTRACT}

This study aims to compare the financial performance before and after the conversion from conventional systems to sharia at PT. Bank Aceh Syariah. Measurement of financial performance using the RGEC model (Risk Profile, GCG, Earnings, Capital). The Risk Profile indicator is measured using the ratio of NPF (Non Performance Financing) and FDR (Financing to Deposit Ratio), $G C G$ ratings are measured using a composite value, then the Earnings indicator uses the ratio of ROA (Return on Total Assets) and ROE Return on Total Equity. capital (Capital) is measured using the ratio of CAR (Capital Adequacy Ratio). Research observation data uses financial reports and published annual reports for a period of three years (2013-2015) before conversion and three years (2016-2018) after conversion. Testing data analysis using Paired T-Test on paired samples, while the normality test of data using Shapiro-Wilk and Wilcoxon. Based on the results of analysis and testing, it is concluded that there are differences in financial performance before and after conversion as measured by the ratio of NPF and ROA. Meanwhile, the financial performance as measured by the ratio of FDR, ROE, $C A R$ and GCG did not show significant differences.

KEYWORDS: Financial Performance; Liquidity; GCG; Profitability; Capital.

\section{ABSTRAK}

Penelitian ini bertujuan untuk membandingkan kinerja keuangan sebelum dan sesudah dilakukannya konversi dari sistem konvensional menjadi syariah pada PT. Bank Aceh Syariah. Pengukuran kinerja keuangan menggunakan model RGEC (Risk Profile, GCG, Earnings, Capital). Indikator Risk Profile diukur menggunakan rasio NPF (Non Performance Financing) dan FDR (Financing to Deposit Ratio), peringkat GCG diukur menggunakan nilai komposit, selanjutnya indikator Earnings menggunakan rasio ROA (Return on Total Asset) dan ROE Return on Total Equity), sedangkan indikator permodalan (Capital) diukur menggunakan rasio CAR (Capital Adequacy Ratio). Data observasi penelitian menggunakan laporan keuangan dan laporan tahunan publikasi periode tiga tahun (2013-2015) sebelum konversi dan tiga tahun (2016-2018) sesudah konversi. Pengujian analisis data menggunakan Paired T-Test pada sampel berpasangan, sedangkan uji normalitas data menggunakan Shapiro-Wilk dan Wilcoxon. Berdasarkan hasil analisis dan pengujian disimpulkan bahwa terdapat perbedaan kinerja keuangan sebelum dan sesudah konversi yang diukur dengan rasio NPF dan ROA. Sedangkan kinerja keuangan yang diukur dengan rasio FDR, ROE, CAR dan GCG tidak menunjukkan perbedaan yang signifikan.

KATA KUNCI: Kinerja Keuangan, Likuiditas, GCG, Profitabilitas, Modal. 


\section{PENDAHULUAN}

Penilaian kesehatan bank secara mandiri (self-assessment) merupakan kewajiban yang harus dijalankan oleh setiap perbankan. Di dalam Peraturan Bank Indonesia Nomor 13/1/PBI/2011 dinyatakan bahwa agar kepercayaan masyarakat terhadap bank tetap terjaga, maka tingkat kesehatan bank harus terus dipelihara dan/atau ditingkatkan. Sementara itu, Otoritas Jasa Keuangan (OJK) sebagai regulator industry keuangan Indonesia juga mengaturnya melalui Peraturan OJK No.8/POJK.03/2014 tentang "Penilaian Tingkat Kesehatan Bank Umum Syariah dan Unit Usaha Syariah". Kinerja kesehatan bank juga digunakan sebagai salah satu indikator evaluasi kondisi dan permasalahan yang dihadapi serta menentukan strategi untuk mengatasi kelemahan atau permasalahan yang dihadapi tersebut. Evaluasi tersebut dilakukan oleh pihak manajemen bank, Otoritas Jasa Keuangan, dan Bank Indonesia sebagai regulator perwakilan pemerintah.

Tanggung jawab dari manajemen bank adalah menjaga tingkat kesehatan bank, dan mengelola keberlangsungan usaha bank. Sehingga, setiap bank secara berkala diwajibkan untuk melakukan penilaian mandiri (self-assessment) (Surat Edaran BI No.13/24/DPNP/2011). Adapun penilaian tersebut sebagai upaya perbaikan secara preventif dengan menggunakan indikator metode RGEC. Metode RGEC terdiri dari 4 (empat) komponen yaitu; Risiko (risk), GCG (good corporate governance), Rentabilitas (earnings), dan Permodalan (capital).

Berdasarkan Peraturan BI Nomor 13/24/DPNP tahun 2011, penilaian terhadap indikator risk profile dilakukan terhadap risiko kredit, risiko pasar, risiko likuiditas, risiko operasional, risiko hukum, risiko stratejik, risiko kepatuhan, dan risiko reputasi. Penilaian profil risiko tersebut merupakan penilaian terhadap risiko inheren dan kualitas penerapan manajemen risiko dalam operasional bank. Selain itu, dijelaskan juga melalui Peraturan OJK No.8/POJK.03/2014 bahwa "penilaian profil risiko pada bank umum syariah selain menggunakan delapan faktor risiko seperti tersebut di atas, juga ditambah dengan dua profil risiko lainnya yaitu risiko imbal hasil dan risiko investasi”.

Setiap bank di Indonesia diwajibkan memasukkan indikator Good Corporate Governance (GCG) sebagai salah satu faktor penilaian tingkat kesehatan bank. Tujuannya agar dapat memperoleh predikat penerapan "tata kelola perusahaan yang baik" (Peraturan BI No.13/1/PBI/2011). Berdasarkan Surat Edaran BI No.12/13/DPbS/2010 dinyatakan bahwa pelaksanaan GCG pada industri perbankan (syariah) harus berlandaskan pada lima prinsip dasar yaitu, "transparansi (transparency), akuntabilitas (accountability), pertanggungjawaban (responsibility), profesional (professional) dan kewajaran (fairness)".

Indikator penilaian kesehatan selanjutnya adalah rentabilitas, dimana rentabilitas adalah kemampuan bank dalam menghasilkan laba selama periode tertentu. Dengan kata lain rentabilitas merupakan perbandingan antara laba dengan aset atau ekuitas yang menghasilkan laba tersebut. Adapun tujuan analisis rentabilitas adalah untuk mengukur keuntungan dan tingkat efisiensi usaha yang dicapai suatu bank selama periode tertentu. Dalam surat edaran OJK dinyatakan bahwa penilaian rentabilitas bank meliputi evaluasi terhadap kinerja rentabilitas, sumber-sumber rentabilitas, kesinambungan rentabilitas, dan manajemen rentabilitas (SE OJK No.10/SE.OJK.03/2014).

4.2 Selanjutnya, indikator penilaian kesehatan yang terakhir berdasarkan metode RGEC adalah faktor kecukupan modal. Kecukupan modal sendiri merupakan salah satu indikator yang penting dalam mengantisipasi potensi risiko suatu bank di masa mendatang, pengembangan 
usaha dan menampung potensi risiko kerugian di masa mendatang. Adapun penilaian terhadap kecukupan dan pengelolaan permodalan suatu bank diatur dalam Peraturan BI No.13/24/DPNP/2011. Taswan (2010) menyatakan bahwa "semakin besar penempatan dana pada aset berisiko tinggi, maka semakin rendah rasio kecukupan modal. Sebaliknya jika penempatan dana pada aset yang berisiko rendah maka dapat menaikkan tingkat kecukupan modal".

Penelitian sebelumnya terkait penilaian kinerja keuangan (kesehatan) perbankan sudah banyak dilakukan, antara lain oleh Anggraini, Yuliani, \& Umrie (2017). Mereka menganalisis tingkat kesehatan pada bank BNI Syariah dan BCA Syariah sebelum dan sesudah dilakukannya spin-off. Dimana hasil penelitian tersebut menyatakan bahwa laba bersih yang diproksikan dengan rasio ROA mengalami peningkatan setelah peristiwa spin-off.

Selanjutnya, penelitian Norfitriani (2016) mengukur tingkat efisiensi dan produktivitas bank sebelum dan sesudah peristiwa spin-off, pada bank BRI Syariah, BNI Syariah dan BJB Syariah. Hasil penelitian tersebut menyatakan bahwa pada BRI Syariah dan BJB Syariah mengalami penurunan tingkat efisiensi sesudah spin off, sedangkan pada BNI Syariah mengalami peningkatan. Sementara itu, tingkat produktivitas pada BRI Syariah dan BNI Syariah mengalami peningkatan sesudah peristiwa spin off, sedangkan pada bank BJB Syariah mengalami penurunan.

Chotib \& Utami (2016) dalam penelitiannya mengukur kinerja keuangan pada bank BNI Syariah sesudah dilakukannya spin off dari induknya Bank BNI, (Persero) Tbk. Dimana, hasil penelitian tersebut menunjukkan bahwa kinerja BNI Syariah tidak mengalami perbedaan antara sebelum dan sesudah peristiwa spin off. Selain itu, hasil perbandingan kinerja antara BNI Syariah dan BJB Syariah juga tidak mengalami perbedaan yang signifikan setelah spin off. Adapun indikator kinerja tersebut menggunakan rasio NPF, FDR, NPM, ROA, ROE, dan CAR.

Indikator pengukuran tingkat kesehatan keuangan lainnya adalah GCG. Penelitian Salin (2018) menganalisis perbedaan kinerja keuangan pada Bank Syariah Mandiri (BSM) sebelum dan sesudah penerapan GCG. Analisis pengukuran menggunakan indikator rasio NPF, FDR, ROA, dan CAR. Hasil penelitian tersebut menunjukkan bahwa jika dilihat dari rasio NPF dan ROA maka tidak terdapat perbedaan kinerja sebelum dan sesudah penerapan GCG. Sedangkan berdasarkan indikator likuiditas dan solvabilitas ditemukan perbedaan kinerja yang signifikan baik sebelum maupun sesudah penerapan GCG.

Penelitian pendukung lainnya yang menganalisis perbedaan kinerja keuangan sebelum maupun sesudah implementasi GCG adalah Sari (2009), namun penelitian tersebut bukan pada perbankan melainkan pada perusahaan manufaktur (Petrokimia Gresik). Indikator pengukuran menggunakan delapan rasio (ROE, ROI, Cash Ratio, Current Ratio, CP, PP, TATO, dan rasio Modal Sendiri terhadap Total Asset). Hasil penelitian tersebut menunjukkan bahwa tidak terdapat perbedaan kinerja keuangan antara sebelum dan sesudah penerapan GCG dilihat dari rasio ROE, ROI, Cash Ratio, Current Ratio, CP, PP, TATO. Sedangkan jika dilihat dari rasio Modal sendiri terhadap Total Asset maka terdapat perbedaan kinerja keuangan antara sebelum dan sesudah penerapan GCG.

Hasil penelitian Maradita (2014) dan Ardhanareswari (2017) juga menyatakan bahwa secara umum tidak terdapat perbedaan pelaksanaan GCG pada bank umum syariah maupun konvensional. Namun, yang menjadi pembeda diantara pelaksanaan GCG pada bank konvensional maupun syariah adalah adanya kepatuhan syariah (shariah compliance), dimana pada bank syariah terdapat Dewan Pengawas Syariah (DPS) dan adanya Dewan Syariah Nasional. 
Nasuha (2012) dalam penelitiannya yang menganalisis dampak kebijakan spin-off terhadap 291 kinerja beberapa bank syariah di Indonesia (BNI Syariah, BRI Syariah, BJB Syariah, Bank Syariah Bukopin, dan Bank Victoria Syariah). Indikator pengukuran menggunakan Aset, Pembiayaan, Dana Pihak Ketiga (DPK), Pendapatan Bersih, Rasio NPF, FDR, ROA, ROE, dan CAR. Dimana, hasil penelitian tersebut menunjukkan bahwa terdapat perbedaan kinerja sebelum dan sesudah spin-off berdasarkan indikator Aset, Pembiayaan, dan DPK. Namun, jika dilihat dari indikator rasio FDR, ROA, ROE dan CAR tidak menunjukkan perbedaan kinerja sebelum maupun sesudah spin-off.

Sementara itu, penelitian Fatmasari \& Kholmi (2018) mengukur kinerja perbankan syariah di Indonesia menggunakan pendekatan yang sedikit berbeda yaitu melalui Islamicity Performance Index. Aspek yang digunakan untuk mengukur kinerja keuangan tersebut antara lain; profit sharing ratio, zakat performance index, qardh, employes expenses, dividen, net profit. Hasil penelitian tersebut menunjukkan bahwa rasio qardh yang paling baik pada BNI Syariah. Selanjutnya untuk rasio employess expense yang paling baik adalah BCA Syariah, sedangkan rasio distribusi dividen yang paling baik adalah Bank Syariah Mandiri.

Berdasarkan hasil penelitian-penelitian sebelumnya tersebut adalah menganalisis kinerja keuangan bank di Indonesia dengan melakukan uji beda sebelum dan sesudah. Akan tetapi, semua penelitian tersebut berfokus pada peristiwa spin-off di bank syariah yang menjadi bagian dari induknya (bank konvensional). Perbedaan penelitian ini dengan penelitian sebelumnya yaitu penelitian ini mengukur perubahan kinerja keuangan pada bank konvensional yang berubah menjadi bank syariah. Seperti yang terjadi pada PT. Bank Aceh yang mengkonversi penuh dari sistem konvensional menjadi syariah. Disinilah letak perbedaan mendasar penelitian ini dengan penelitian sebelumnya, dimana penulis bertujuan menganalisis apakah terdapat perbedaan kinerja keuangan antara sebelum dan sesudah peristiwa konversi syariah pada Bank Aceh.

Sebagai Bank milik Pemerintah Aceh, PT Bank Aceh Syariah merupakan bank pertama di Aceh yang didirikan pada tanggal 19 November 1958 dengan nama awalnya NV. Bank Kesejateraan Atjeh (disingkat BKA). Selanjutnya pada tanggal 7 Mei 1999 terjadi perubahan nama menjadi PT. Bank Pembangunan Daerah Istimewa Aceh (PT. Bank BPD Aceh). Sepuluh tahun kemudian dirubah kembali namanya menjadi PT. Bank Aceh pada tanggal 29 September 2010. Terakhir kalinya tepat pada tanggal 19 September 2016, PT. Bank Aceh dikonversi seara penuh menjadi Bank Umum Syariah (BUS) dan berganti nama menjadi PT. Bank Aceh Syariah.

Berdasarkan permasalahan yang telah dikemukakan di atas, penelitian ini bertujuan menganalisis kinerja keuangan bank (baca: Bank Aceh Syariah) menggunakan metode RGEC. Dimana, Risk profile diukur menggunakan rasio NPF dan FDR, GCG diukur menggunakan peringkat komposit, Earnings diukur menggunakan ROA dan ROE, sedangkan Capital diukur menggunakan rasio CAR.

\section{METODE}

Jenis penelitian ini termasuk penelitian deskriptif kuantitatif dengan objek observasi pada kinerja keuangan PT Bank Aceh Syariah. Pengukuran kinerja keuangan tersebut dilakukan antara sebelum dan sesudah peristiwa konversi (dari sistem konvensional ke sistem syariah) secara penuh. Pengujian dilakukan menggunakan uji beda Paired TTest. Pengukuran tingkat kesehatan bank berdasarkan metode RGEC yang terdiri dari rasio NPF, FDR, GCG, ROA, ROE, dan CAR. Sumber data menggunakan data sekunder yang diunduh langsung dari website perusahaan (www.bankaceh.co.id). Jenis 
data yang digunakan adalah laporan keuangan dan laporan tahunan publikasi periode 2013-2018.

\section{Teknik Analisis Data}

Adapun beberapa tahapan yang harus dilalui dalam menganalisis kinerja keuangan dengan menggunakan metode RGEC dapat dijelaskan sebagai berikut:

1) Menghitung rasio NPF, FDR, GCG, ROA, ROE dan CAR.

2) Menganalisis deskriptif terhadap hasil perhitungan rasio.

3) Melakukan pengujian hipotesis menggunakan uji statistik paired t test.

4) Menentukan taraf signifikansi $\alpha=5 \%$ atau $\alpha=0,05$.

5) Menganalisis hasil statistik deskriptif.

6) Membuat kesimpulan penelitian.

7) Analisis data menggunakan software SPSS versi 21.

\section{HASIL DAN PEMBAHASAN}

\section{Kinerja Keuangan Bank Aceh Selama 2013 hingga 2018}

Berikut adalah data kinerja keuangan Bank Aceh antara sebelum konversi (2013-2015) dan sesudah konversi (2016-2018) yang dapat dilihat pada Tabel 1 di bawah ini:

Tabel 1.

\begin{tabular}{cccccccc}
\hline No & Variabel & $\mathbf{2 0 1 3}$ & $\mathbf{2 0 1 4}$ & $\mathbf{2 0 1 5}$ & $\mathbf{2 0 1 6}$ & $\mathbf{2 0 1 7}$ & $\mathbf{2 0 1 8}$ \\
\hline 1 & NPF & 2,78 & 2,58 & 2,30 & 1,39 & 1,38 & 1,04 \\
2 & FDR & 86,80 & 92,38 & 84,05 & 84,59 & 69,44 & 71,98 \\
3 & GCG & 2 & 2 & 2 & 2 & 3 & 3 \\
4 & ROA & 3,44 & 3,22 & 2,83 & 2,48 & 2,51 & 2,38 \\
5 & ROE & 23,57 & 23,62 & 24,24 & 19,78 & 23,11 & 23,29 \\
6 & CAR & 17,56 & 19,93 & 19,44 & 20,74 & 21,50 & 19,67 \\
\hline
\end{tabular}

Sumber: Data sekunder 2013-2018 (diolah)

Berdasarkan tabel di atas, hasil perhitungan pada rasio NPF selama enam tahun menunjukkan bahwa risiko kredit Bank Aceh memiliki kecenderungan yang semakin baik, karena berdasarkan kriteria penetapan penilaian NPF memiliki rasio dibawah 2\% $(<2 \%)$ pada tahun 2013-2018. Hingga tahun 2018, rasio NPF turun menjadi 1,04 \%. Artinya, pembiayaan bermasalah pada tahun 2018 sangat rendah, sehingga risiko kegagalan pembiayaan yang kemungkinan akan terjadi juga sangat kecil.

Rasio FDR selama 6 tahun juga menunjukkan kecenderungan yang semakin baik. Berdasarkan kriteria penilaian FDR selama tahun 2013 hingga 2018 memiliki rasio 69-92\%. Dimana, pemerintah menetapkan maksimum rasio FDR bank sebesar 110\%. Rasio FDR yang rendah menandakan bank sedang dalam keadaan yang baik (likuid) dengan memiliki kelebihan kapasitas dana yang siap disalurkan kembali. Namun, jika pembiayaan yang disalurkan semakin menurun maka pendapatan juga akan berkurang.

Perkembangan kinerja GCG selama enam tahun terakhir juga dalam kategori "cukup baik". Berdasarkan self assesment penilaian GCG pada Bank Aceh Syariah dari tahun 2013-2018 dapat dilihat secara umum tatakelola perusahaan sudah cukup baik, sesuai dengan kategori Peringkat Komposit OJK (Peraturan OJK No.8/POJK.03/2014) yaitu; (a) Peringkat Komposit 1 (PK-1), Sangat Sehat, (b) Peringkat Komposit 2 (PK-2), Sehat, (c) Peringkat 
Komposit 3 (PK-3), Cukup Sehat; (d) Peringkat Komposit 4 (PK-4), Kurang Sehat, (e) 293 Peringkat Komposit 5 (PK-5), Tidak Sehat.

Berdasarkan perhitungan rasio ROA dari tahun 2013-2018 memiliki kecenderungan menurun. Dimana nilai ROA tahun 2013 sebesar 3,44\%, sedangkan tahun 2018 sebesar $2,38 \%$ sedikit turun dibandingkan tahun-tahun sebelumnya. Namun, penurunan tersebut masih dalam kategori perolehan laba yang "tinggi" (diatas 1,25\%). Hal ini berdasarkan kriteria penetapan peringkat ROA perbankan menurut standar minimum Bank Indonesia (SE BI No.6/23/DPNP/2004).

Selain ROA, rasio ROE juga digunakan untuk mengukur kemampuan perusahaan menghasilkan profitabilitas. Berdasarkan perhitungan di atas dapat diketahui bahwa rasio ROE Bank Aceh Syariah berkisar pada angka 23\%, serta memiliki tren yang relatif stabil dari tahun 2013-2018. Jika mengacu pada kriteria ROE berdasarkan standar minimum Bank Indonesia (SE BI No.6/23/DPNP/2004), nilai ROE Bank Aceh Syariah sebesar 23\% masuk dalam kategori "sangat tinggi".

Selanjutnya, berdasarkan penilaian rasio CAR dari tahun 2013 hingga 2018 memiliki tren yang positif, dimana rasio CAR tersebut berkisar diantara 17-21\%. Berdasarkan ketentuan Bank Indonesia tentang "Kewajiban Penyediaan Modal Minimum (KPMM) bank umum berdasarkan prinsip syariah ditetapkan sebesar 10-11\%". Sehingga rasio kecukupan modal (CAR) Bank Aceh Syariah selama selama enam tahun (2013-2018) masuk dalam kategori "sangat memuaskan".

\section{Pengujian Hipotesis}

\section{Pengujian Paired Samples Statistics}

Nilai signifikansi hasil pengujian hipotesis dengan menggunakan Paired T-test yang dilakukan terhadap variabel NPF, FDR, ROA, ROE, dan CAR dengan menggunakan program SPSS dapat dilihat pada tabel di bawah ini, sedangkan untuk variabel GCG akan dilakukan menggunakan Uji Wilcoxon.

\begin{tabular}{clcccc}
\hline & & Mean & N & $\begin{array}{c}\text { Std. } \\
\text { Deviation }\end{array}$ & $\begin{array}{c}\text { Std. Error } \\
\text { Mean }\end{array}$ \\
\hline \multirow{2}{*}{ Pair 1 } & NPF_Sebelum & 2.5533 & 3 & .24111 & .13920 \\
& NPF_Sesudah & 1.2700 & 3 & .19925 & .11504 \\
Pair 2 & FDR_Sebelum & 87.7433 & 3 & 4.24436 & 2.45049 \\
& FDR_Sesudah & 75.3367 & 3 & 8.11363 & 4.68441 \\
Pair 3 & ROA_Sebelum & 3.1633 & 3 & .30892 & .17836 \\
& ROA_Sesudah & 2.4567 & 3 & .06807 & .03930 \\
Pair 4 & ROE_Sebelum & 23.8100 & 3 & .37323 & .21548 \\
& ROE_Sesudah & 22.0600 & 3 & 1.97659 & 1.14118 \\
Pair 5 & CAR_Sebelum & 18.9767 & 3 & 1.25109 & .72232 \\
& CAR_Sesudah & 20.6367 & 3 & .91937 & .53080 \\
\hline
\end{tabular}

Tabel 2.

Paired Samples Statistics

Sumber: Data sekunder 2013-2018 (diolah)

JAA Hasil perhitungan Paired Samples Statistics pada tabel 2 di atas menunjukkan bahwa nilai ratarata (mean) NPF, FDR, ROA, ROE dan CAR sebelum dan sesudah konversi syariah.

4.2 Jumlah data yang digunakan sebagai sampel sebanyak 3 tahun. Karena nilai rata-rata (mean) masing-masing variabel, baik sebelum maupun sesudah konversi lebih besar dari NPF 
sesudah konversi berbeda, artinya secara deskriptif terdapat perbedaan rata-rata nilai NPF, FDR, ROA, ROE dan CAR.

\section{Pengujian Paired Samples Correlations}

Sementara itu, untuk menguji hubungan antara kedua data sebelum dan sesudah konversi syariah dapat dilihat pada tabel Paired Samples Correlations berikut ini.

\begin{tabular}{llccc}
\hline & & N & Correlation & Sig. \\
\hline Pair 1 & $\begin{array}{l}\text { NPF_Sebelum \& } \\
\text { NPF_Sesudah }\end{array}$ & 3 & .920 & .256 \\
Pair 2 & $\begin{array}{l}\text { FDR_Sebelum \& } \\
\text { FDR_Sesudah }\end{array}$ & 3 & -.344 & .777 \\
Pair 3 & $\begin{array}{l}\text { ROA_Sebelum \& } \\
\text { ROA_Sesudah }\end{array}$ & 3 & .833 & .373 \\
Pair 4 & $\begin{array}{l}\text { ROE_Sebelum \& } \\
\text { ROE_Sesudah } \\
\text { CAR_Sebelum \& }\end{array}$ & 3 & .594 & .595 \\
Pair 5 & 3 & .099 & .937 \\
\hline
\end{tabular}

Sumber: Data sekunder 2013-2018 (diolah)

Berdasarkan tabel 3 di atas diketahui nilai koefisien korelasi (correlation) variabel NPF, FDR, ROA, ROE, dan CAR masing-masing dengan nilai signifikansi (Sig.) sebesar 0.256, 0.777, 0.373, 0.595, dan 0.937. Karena nilai signifikansi semua variabel lebih besar dari probabilitas 0.05 (>0.05), maka dapat disimpulkan bahwa tidak terdapat hubungan signifikan antara variabel NPF, FDR, ROA, ROE, dan CAR baik sebelum konversi maupun sesudah dilakukannya konversi ke sistem syariah.

\section{Pengujian Hipotesis Menggunakan Paired Samples Test (Uji-T)}

Setelah melakukan uji paired samples statistics dan paired samples correlation, langkah selanjutnya adalah melakukan Uji T untuk data variabel NPF, FDR, ROA, ROE, dan CAR dengan menggunakan pengujian paired sample test. Hasil pengujian secara statistik dengan uji hipotesis paired sample test dapat dilihat pada tabel di bawah ini:

Tabel 4.

\begin{tabular}{|c|c|c|c|c|c|c|c|c|c|}
\hline & & \multicolumn{5}{|c|}{ Paired Differences } & \multirow{3}{*}{$\mathrm{t}$} & \multirow{3}{*}{ df } & \multirow{3}{*}{$\begin{array}{c}\text { Sig. } \\
\text { (2-tailed) }\end{array}$} \\
\hline & & \multirow[t]{2}{*}{ Mean } & \multirow[t]{2}{*}{$\begin{array}{c}\text { Std. } \\
\text { Deviation }\end{array}$} & \multirow{2}{*}{$\begin{array}{l}\text { Std. } \\
\text { Error } \\
\text { Mean }\end{array}$} & \multicolumn{2}{|c|}{$\begin{array}{l}95 \% \text { Confidence } \\
\text { Interval of the } \\
\text { Difference }\end{array}$} & & & \\
\hline & & & & & Lower & Upper & & & \\
\hline Pair 1 & NPF_Sebelum - Sesudah & 1.28333 & .09713 & .05608 & 1.04206 & 1.52461 & 22.886 & 2 & .002 \\
\hline Pair 2 & FDR_Sebelum - Sesudah & 12.40667 & 10.36910 & 5.98660 & -13.35161 & 38.16494 & 2.072 & 2 & .174 \\
\hline Pair 3 & ROA_Sebelum - Sesudah & .70667 & .25502 & .14723 & .07317 & 1.34016 & 4.800 & 2 & .041 \\
\hline Pair 4 & ROE_Sebelum - Sesudah & 1.75000 & 1.78034 & 1.02788 & -2.67260 & 6.17260 & 1.703 & 2 & .231 \\
\hline Pair 5 & CAR_Sebelum - Sesudah & -1.66000 & 1.47706 & .85278 & -5.32922 & 2.00922 & -1.947 & 2 & .191 \\
\hline
\end{tabular}

Sumber: Data sekunder 2013-2018 (diolah) 


\section{Pengujian Hipotesis Menggunakan Uji Wilcoxon Signed Ranks Test}

Berdasarkan hasil output uji normalitas Shapiro-Wilk nilai signifikansi variabel GCG sebelum dan sesudah konversi lebih kecil dari $0.05(<0.05)$, sehingga dapat disimpulkan bahwa variabel GCG tidak berdistribusi normal. Karena data tidak berdistribusi normal maka pengujian hipotesis menggunakan uji Wilcoxon (wilcoxon signed ranks test). Uji wilcoxon merupakan salah satu metode pengujian hipotesis statistik non parametrik untuk sampel berpasangan. Tabel berikut adalah output hasil pengujian statistik menggunakan Wilcoxon Signed Ranks Test.

\begin{tabular}{lc}
\hline & Sesudah - Sebelum \\
\hline $\mathrm{Z}$ & $-1.414^{\mathrm{b}}$ \\
Asymp. Sig. (2-tailed) & .157 \\
\hline
\end{tabular}

Sumber: Data sekunder 2013-2018 (diolah)

Berdasarkan output Tabel 5 di atas diketahui nilai Asymp. Sig. (2-tailed) adalah 0.157. Karena nilai 0.157 lebih besar dari 0.05 (>0.05), maka dapat disimpulkan bahwa " $\mathrm{H}_{0}$ diterima dan $\mathrm{H}_{\mathrm{a}}$ ditolak". Artinya tidak terdapat perbedaan antara nilai GCG pada Bank Aceh Syariah sebelum konversi maupun sesudah dilakukannya konversi ke sistem syariah. Artinya, nilai peringkat GCG pada Bank Aceh Syariah tidak dipengaruhi oleh penerapan sistem konvensional maupun sistem syariah.

\section{Pembahasan}

\section{Hasil Pengujian Hipotesis Pertama (H1)}

Berdasarkan hasil analisis Paired Samples Test pada Tabel 4 di atas bahwa nilai rata-rata (mean) rasio NPF sebesar 1.28333, dengan standar deviasi sebesar 0.09713, nilai t-hitung sebesar 22.886, dengan nilai signifikansi (Sig.) sebesar 0.002 lebih kecil dari $0.05(0.002<0.05)$, maka hipotesis $\mathrm{H}_{0}$ ditolak dan $\mathrm{H}_{a}$ diterima. Dapat disimpulkan bahwa terdapat perbedaan signifikan pada rasio NPF Bank Aceh Syariah sebelum dan sesudah konversi ke syariah.

Hal tersebut menunjukkan bahwa rasio NPF sebelum dan sesudah konversi memiliki risiko kredit yang semakin rendah. Artinya, pembiayaan bermasalah pada Bank Aceh Syariah semakin menurun pasca diberlakukannya konversi syariah. Penurunan pembiayaan bermasalah tersebut turut meningkatkan pendapatan bank, dimana pada tahun 2016-2018 pasca konversi Bank Aceh mendapatkan peningkatan laba bersih.

Hasil penelitian ini sejalan dengan penelitian Anggraini, et al. (2017) yang menyatakan bahwa terdapat perbedaan signifikan pada rasio NPF Bank BNI Syariah dan BCA Syariah setelah adanya peristiwa spin off. Begitu juga Nasuha (2012) menyatakan bahwa terdapat perbedaan kinerja NPF pada bank syariah yang melakukan spin off. Walaupun kedua penelitian tersebut mengukur rasio NPF pada peristiwa sebelum dan sesudah spin off, namun penelitian ini mengukur sebelum dan setelah peristiwa konversi dari konvensional ke sistem syariah.

JAA Sementara itu, hasil penelitian ini berbeda dengan Chotib dan Utami (2014) yang menyatakan bahwa nilai signifikansi NPF pada BNI Syariah sebelum spin off tidak berbeda 4.2 dengan sesudah spin off. Begitu juga penelitian $\underline{\text { Salin (2018) }}$ tidak menemukan perbedaan kinerja sebelum dan sesudah penerapan GCG, jika dilihat dari rasio NPF. 


\section{Hasil Pengujian Hipotesis Kedua (H2)}

Untuk variabel rasio FDR diketahui nilai rata-ratanya sebesar 12.40667, dengan standar deviasi sebesar 10.36910, nilai t-hitung sebesar 2.072, dan nilai signifikansi (Sig.) sebesar 0.174 lebih besar dari $0.05(0.174>0.05)$, sehingga hipotesis $\mathrm{H}_{0}$ diterima sedangkan $\mathrm{H}_{\mathrm{a}}$ ditolak. Dapat disimpulkan bahwa tidak terdapat perbedaan signifikan pada rasio FDR Bank Aceh sebelum dan sesudah konversi konvensional ke syariah.

Hasil penelitian ini sejalan dengan Nasuha (2012:255-256) yang menunjukkan bahwa tidak terdapat perbedaan kinerja rasio FDR Bank Syariah (BNI, BRI, BJB, Bukopin, Victoria) menggunakan periode perbandingan satu tahun sebelum dan satu tahun sesudah spin off. Begitu juga penelitian Chotib dan Utami (2014) menyatakan bahwa rata-rata FDR BNI Syariah sebelum spin off tidak berbeda signifikan dibandingkan sesudah spin off. Selanjutnya penelitian Norfitriani (2016) mengukur efisiensi dan produktivitas bank syariah di Indonesia (BRIS, BNIS, BJBS), menemukan bahwa tidak terdapat perbedaan signifikan efisiensi dan produktivitas, baik sebelum maupun sesudah spin off. Dimana salah satu variabel pengukuran efisiensi menggunakan Dana Pihak Ketiga (DPK) atau bisa diukur juga dengan rasio FDR.

Sementara itu, penelitian $\underline{\text { Salin (2018) }}$ menemukan bahwa "terdapat perbedaan kinerja yang signifikan sebelum dan sesudah penerapan GCG jika dilihat dari rasio likuiditas yang diukur menggunakan FDR pada Bank Syariah Mandiri”. Salah satu kesimpulan penelitian Chotib dan Utami (2014) menyatakan bahwa rata-rata FDR BNI Syariah dan BJB Syariah tidak berbeda signifikan sesudah spin off.

Somantri \& Sukmana (2019) menyatakan bahwa faktor yang mempengaruhi naik turunnya Financing to Deposit Ratio (FDR) diprediksi berasal dari kondisi internal maupun eksternal perbankan. Kondisi internal dapat tercermin dari rasio keuangan suatu bank. Sedangkan kondisi eksternal dapat tercermin dari keadaan makro ekonomi suatu negara.

Temuan dalam penelitian ini menunjukkan bahwa rasio FDR pada Bank Aceh tidak mengalami perubahan yang signifikan antara sebelum dan sesudah dilakukan konversi dari sistem konvensional ke syariah. Hal ini dapat dilihat dari rasio FDR selama 6 tahun (2013 hingga 2018) berada pada rasio 69-92\%. Artinya, peralihan dari sistem konvensional ke syariah belum menunjukkan perubahan yang signifikan dari sisi penyaluran pembiayaan pada Bank Aceh Syariah.

\section{Hasil Pengujian Hipotesis Ketiga (H3)}

Khusus variabel GCG, berdasarkan output pada tabel 5 diketahui nilai signifikansi sebesar 0.157. Karena nilai signifikansi lebih besar dari $0.05(0.157>0.05)$, maka dapat disimpulkan bahwa " $\mathrm{H}_{0}$ diterima dan $\mathrm{H}_{\mathrm{a}}$ ditolak". Artinya tidak terdapat perbedaan antara nilai GCG pada Bank Aceh Syariah sebelum maupun sesudah dilakukannya konversi syariah. Hal ini berarti bahwa nilai peringkat GCG pada Bank Aceh Syariah tidak dipengaruhi oleh penerapan sistem konvensional maupun sistem syariah.

Jika melihat kembali kinerja GCG Bank Aceh Syariah selama enam tahun terakhir yaitu, tahun 2013-2016 berada pada peringkat 2 (sehat) sedangkan tahun 2017-2018 berada pada peringkat 3 (cukup sehat). Walaupun dalam dua tahun terakhir mengalami penurunan peringkat dari "sehat" menjadi "cukup sehat", namun secara umum mencerminkan bahwa manajemen bank telah melakukan penerapan GCG. Ngumar, et al. (2019) menyatakan, secara teori jika prinsip GCG diterapkan dengan baik dapat mencegah terjadinya penyimpangan (fraud), karena bank merupakan entitas yang mengelola dana masyarakat, 
GCG kemudian dianggap sebagai faktor yang dapat mengendalikan penyelewengan pada entitas binsis termasuk bank syariah.

Penelitian Ardhanareswari (2017) pada Bank BNI Syariah dan BRI Syariah menemukan bahwa kedua bank tersebut memiliki peringkat GCG yang tinggi (BAIK) pada tahun 2015, dan pada dasarnya pelaksanaan GCG pada bank konvensional maupun syariah tidak memiliki perbedaan yang signifikan. Penelitian sebelumnya oleh Maradita (2014) juga telah menegaskan bahwa yang menjadi pembeda diantara pelaksanaan GCG pada bank konvensional maupun syariah adalah adanya syariah compliance yaitu kepatuhan pada syariah, kemudian adanya Dewan Pengawas Syariah (DPS) serta adanya Dewan Syariah Nasional.

Hasil penelitian ini belum dapat dibandingkan dengan temuan-temuan penelitian sebelumnya. Hingga akhir penelitian ini dilaksanakan, penulis belum mendapatkan hasil penelitian sebelumnya yang menganalisis perubahan peringkat GCG suatu bank sebelum dan sesudah dilakukannya penggabungan usaha, pemisahan usaha maupun perubahan sistem (konversi).

\section{Hasil Pengujian Hipotesis Keempat (H4)}

Selanjutnya untuk variabel ROA nilai rata-ratanya (mean) sebesar 0.70667, dengan standar deviasinya sebesar 1.78034 , nilai t-hitung sebesar 4.800 , dan nilai signifikansinya (Sig.) sebesar 0.041 lebih kecil dari $0.05(0.041<0.05)$, sehingga hipotesis $\mathrm{H}_{0}$ ditolak dan $\mathrm{H}_{\mathrm{a}}$ diterima. Dapat disimpulkan bahwa terdapat perbedaan yang signifikan dilihat dari rasio ROA Bank Aceh Syariah, baik sebelum maupun sesudah konversi syariah.

Temuan ini berbeda dengan hasil penelitian Salin (2018), Anggraini, et al. (2017), Norfitriani (2016), Chotib dan Utami (2014), dan Nasuha (2012) yang menyatakan bahwa pada umumnya tidak terdapat perbedaan yang signifikan tingkat kesehatan bank dilihat dari rasio ROA, baik sebelum maupun sesudah peristiwa spin off pada beberapa bank syariah di Indonesia.

Perbedaan temuan penelitian ini dapat disebabkan karena rasio ROA Bank Aceh Syariah tiga tahun sebelum konversi relatif tinggi yaitu, 3.44, 3.22, 2.83, sedangkan setelah konversi ke syariah ROA cenderung menurun menjadi $2.48,2.51,2.38$. Hal inilah yang menyebabkan rasio ROA mengalami perbedaan yang signifikan antara sebelum dan sesudah konversi. Sehingga laba bersih Bank Aceh tetap mengalami pertumbuhan positif sebelum maupun sesudah konversi.

\section{Hasil Pengujian Hipotesis Kelima (H5)}

Sementara itu untuk variabel ROE nilai rata-ratanya (mean) sebesar 1.75000, dan standar deviasinya sebesar 0.25502 , kemudian nilai t-hitung sebesar 1.703 , dan nilai signifikansi (Sig.) sebesar 0.231 lebih besar dari 0.05 (0.231>0.05), sehingga hipotesis $\mathrm{H}_{0}$ diterima dan $\mathrm{H}_{\mathrm{a}}$ ditolak. Dapat disimpulkan bahwa tidak terdapat perbedaan signifikan pada rasio ROE Bank Aceh Syariah sebelum dan sesudah konversi syariah.

Jika diihat rasio ROE Bank Aceh Syariah, terjadi penurunan ROE yang cukup signifikan sesaat setelah konversi di tahun 2016 yang disebabkan oleh penurunan laba perseroan di tahun 2016 sebesar 8,95\% dari tahun sebelumnya. Namun, periode selanjutnya mengalami peningkatan kembali. Peningkatan ini paling besar dipengaruhi oleh kenaikan saldo laba yang ditentukan dan yang belum ditentukan penggunaanya, sehingga secara otomatis rasio

4.2 ROE di tahun 2016 juga menurun.

Hasil penelitian ini sejalan dengan penelitian Chotib dan Utami (2014), Nasuha (2012) dan $\underline{\text { Sari (2009) }}$ yang menyatakan bahwa tidak terdapat perbedaan kinerja keuangan pada 
beberapa perbankan di Indonesia yang telah melakukan spin off jika diukur menggunakan rasio ROE.

\section{Hasil Pengujian Hipotesis Keenam (H6)}

Begitu juga untuk variabel rasio CAR nilai rata-ratanya (mean) sebesar -1.66000 , dengan standar deviasi sebesar 1.47706, nilai t-hitung sebesar -1.947, dengan nilai signifikansi (Sig.) sebesar 0.191 lebih besar dari $0.05(0.191>0.05)$, sehingga hipotesis $\mathrm{H}_{0}$ diterima dan $\mathrm{H}_{\mathrm{a}}$ ditolak. Dapat disimpulkan bahwa tidak terdapat perbedaan signifikan pada rasio CAR Bank Aceh Syariah sebelum dan sesudah konversi syariah.

Hasil penelitian ini sejalan dengan Anggraini, et al. (2017), Chotib dan Utami (2014), dan Nasuha (2012) yang menemukan bahwa rasio CAR sebelum dan sesudah spin off tidak menunjukkan perbedaan signifikan. Sehingga dapat disimpulkan bahwa Bank Aceh memiliki kecukupan modal yang baik dalam memenuhi berbagai kewajiban yang dimilikinya, baik untuk mendanai kegiatan usaha maupun untuk mengantisipasi terjadinya risiko di masa depan.

Akan tetapi, hasil penelitian ini berbeda dengan penelitian Chotib dan Utami (2014) yang menyatakan bahwa rata-rata CAR BNI Syariah sesudah spin off berbeda siginifikan dengan rata-rata CAR BJB Syariah sesudah spin off. Salin (2018) juga menemukan perbedaan kinerja (dilihat dari rasio CAR) sebelum dan sesudah penerapan GCG pada Bank Syariah Mandiri.

\section{SIMPULAN}

Beberapa hal yang dapat disimpulkan dari hasil penelitian ini antara lain, bahwa kinerja keuangan Bank Aceh Syariah jika dilihat dari aspek Risk Profile yang diukur menggunakan rasio NPF terdapat perbedaan signifikan sebelum dan sesudah konversi. Sedangkan jika diukur dengan rasio FDR tidak terdapat perbedaan signifikan baik sebelum maupun sesudah konversi. Begitu juga aspek GCG yang diukur dengan peringkat nilai komposit, hasil penelitian juga tidak terdapat perbedaan signifikan sebelum dan sesudah konversi syariah. Aspek Earnings bank yang diukur dengan ROA ternyata terdapat perbedaan signifikan sebelum dan sesudah konversi, sedangkan jika dilihat dengan rasio ROE tidak ada perbedaan yang signifikan sebelum maupun sesudah konversi syariah. Selanjutnya, kinerja keuangan yang dilihat dari aspek Capital juga menunjukkan tidak ada perbedaan signifikan pada rasio CAR sebelum dan sesudah konversi ke syariah.

Beberapa keterbatasan dan saran pada penelitian ini antara lain; a) Pengamatan hanya 6 tahun (2013-2018) dikarenakan data pembanding sebelum dan sesudah konversi yang digunakan pada saat penelitian ini terbatas hingga tahun 2018, sehingga untuk hasil yang lebih komprehensif dapat menggunakan rentang waktu yang lebih panjang; b) Unit analisis masih terbatas pada Bank Aceh Syariah dan pengukuran kinerja masih terbatas menggunakan deskriptif analisis sehingga untuk penelitian selanjutnya dapat menggunakan perbandingan pada beberapa bank syariah atau konvensional di Indonesia; c) Pengujian juga masih terbatas menggunakan Uji Beda, sehingga penelitian selanjutnya dapat mengembangkan menggunakan uji pengaruh maupun hubungan; d) Bagi Bank Aceh Syariah diharapkan lebih meningkatkan peringkat GCG menjadi "baik" sehingga dapat lebih meningkatkan kinerja bank, di mana nilai GCG dua tahun terakhir (2017 dan 2018) berada pada peringkat 3 (cukup baik). 


\section{DAFTAR PUSTAKA}

Anggraini, R. (2017). “Analisis Tingkat Kesehatan Bank Syariah Sebelum Dan Sesudah Spin Off”. Ekspektra, 1(1). pp. 11-20. https://doi.org/10.25139/ekt.v1i1.88

Ardhanareswari, R. (2017). "Pelaksanaan dan pengungkapan Good Corporate Governance Pada Bank Umum Syariah". Jurnal Law and Justice, 2(1), 66-78. https://doi.org/https://doi.org/10.23917/laj.v2i1.4338

Bank Indonesia. (2010). Surat Edaran Bank Indonesia Nomor 12/13/DPbS/2010 Tentang Pelaksanaan GCG pada Bank Umum Syariah.

Bank Indonesia. (2011). Peraturan Bank Indonesia Nomor 13/1/PBI/2011 Tentang Penilaian Tingkat Kesehatan Bank Umum.

Chotib, A., \& Utami, W. (2016). "Studi Kinerja PT BNI Syariah Sesudah Pemisahan (Spin Off) dari PT Bank BNI (Persero)". Akuntabilitas, 7(2). pp. 94-108. https://doi.org/10.15408/akt.v7i2.2661

Fatmasari, R., \& Kholmi, M. (2018). Analisis Kinerja Keuangan Perbankan Syariah dengan Pendekatan Islamicity Performance Index pada Perbankan Syariah di Indonesia. Jurnal Akademi Akuntansi, 1(1), 74-83. https://doi.org/https://doi.org/10.22219/jaa.v1i1.6940

Maradita, A. (2014). "Karakteristik Good Corporate Governance pada Bank Syariah dan Bank Konvensional". Yuridika, 29(2), 191-204. https://doi.org/http://dx.doi.org/10.20473/ydk.v29i2.366

Nasuha, A. (2012). "Dampak Kebijakan Spin-Off Terhadap Kinerja Bank Syariah". AlIqtishad, IV(2). pp. 241-258.

Ngumar, S., Fidiana, F., \& Retnani, E. D. (2019). Implications of Islamic Governance on Islamic Bank Fraud. Jurnal Reviu Akuntansi Dan Kenangan, 9(2), 226. https://doi.org/10.22219/jrak.v9i2.8735

Norfitriani, S. (2016). "Analisis Efisiensi dan Produktivitas Bank Syariah di Indonesia Sebelum dan Sesudah Spin-Off'. Jurnal Ekonomi Syariah Indonesia, VI(2). pp. 134-143.

Otoritas Jasa Keuangan. (2014). Peraturan Otoritas Jasa Keuangan Nomor 8/POJK.03/2014 Tentang Penilaian Tingkat Kesehatan Bank Umum Syariah dan Unit Usaha Syariah.

Otoritas Jasa Keuangan. (2014). Surat Edaran Otoritas Jasa Kenangan Nomor 10/SEOJK.03/2014 Tentang Penilaian Tingkat Kesehatan Bank Umum Syariah dan Unit Usaba Syariah.

Otoritas Jasa Keuangan. (2015). Surat Edaran Otoritas Jasa Keuangan Nomor 12/SE.OJK.03/2015 Peribal Kewajiban Penyediaan Modal Minimum sesuai Profil Risiko Bagi Bank. Umum Syariah.

Salin, A. (2018). "Perbedaan Kinerja Keuangan Perbankan Sebelum dan Sesudah Penerapan GCG Studi Kasus pada Bank Syariah Mandiri”. Ekomadania, 1(2). pp. 149-176.

JAA Sari, R. P. (2009). "Analisis Perbedaan Kinerja Keuangan Sebelum dan Sesudah Penerapan

4.2 Prinsip Good Corporate Governance Pada PT Petrokimia Gresik”. Jurnal Riset Ekonomi Dan Bisnis, 9(2). pp. 118-137. 
Budianto, \& Sofyan, Analisis Perbandingan Kinerja ...

Somantri, Y. F., \& Sukmana, W. (2019). "Analisis Faktor- Faktor yang Mempengaruhi Financing to Deposit Ratio (FDR) pada Bank Umum Syariah di Indonesia”. Berkala Akuntansi Dan Keuangan Indonesia, 04(02), 61-71.

Taswan. (2010). Manajemen Perbankan: Konsep, Teknik \& Aplikasi Penjaminan Simpanan \& Penjamin Kredit), Edisi 2. Yogyakarta: UPP STIM YKPN. 